\title{
A Systematic Review of Online Learning during COVID-19 Crisis: An Indian Experience
}

\author{
Rouf Ahmad Bhat \\ Government Degree College Udhampur, J\&K, India. \\ ORCID: 0000-0003-2424-757X
}

Sanjay Kumar

Assistant Professor, Department of Political Science, Government Degree College Udhampur, J\&K, India.

Arshad Ahmad Najar

Government College for Women Parade, Jammu, J\&K, India.

Anita Deshpande

Professor \& HOD, Department of Political Science and Public Administration, Institute for Excellence in Higher Education (IEHE), Bhopal (M.P), India.

\begin{abstract}
In India educational institutions are currently grounded only on traditional methods of learning, they follow the traditional arrangements of face-to-face learning methods in a classroom. Although many educational institutions at different levels (Schools, Colleges, Universities) have also started blended learning, still most of them are stuck with the procedures which are yet to rejuvenate. The sudden burst of CoronaVirus (SARS-CoV-2) shook the entire world and has interrupted all facets of our daily lives. This situation challenged the education system across the world and forced educators to shift to an online mode of teaching overnight. Many academic institutions that were earlier indisposed to change their traditional pedagogical approach had no option but to shift entirely to online teaching-learning. This study elucidates the importance of online learning and elaborates opportunities \& challenges of elearning modes in the time of crisis. This research piece sheds some light on the growth of ITenabled tools (EdTech) during the time of the pandemic. In concluding interpretations this research article places suggestions for academic institutions on how to deal with challenges associated with online learning.
\end{abstract}

Keywords: COVID-19, EdTech, Education, Indian Experience, Information Technology, MOOC, Online Learning, Pandemic.

\section{Introduction}

The deadliest COVID-19 outbreak (previously 2019-nCoV) was caused by the SARS-CoV-2 virus. This outbreak was triggered in December 2019 in Wuhan city in Hubei province of China (Chaplin, 2020). COVID19 continues to spread across the world. Initially, the epicentre of the outburst was China with reported cases either in China or being travellers from China. Covid19 has deeply affected the global economy. Subsequently, it has impacted all levels of the educational system as well, forcing the inclusion of technology tools in education (Shukla and Nirban, June 21, 2020). As a result, this pandemic forced most of the educational institutions 
at all levels to remain temporarily closed. In-person teaching was discontinued in various colleges and universities globally. This has unilaterally created a vacuum in the traditional driven educational culture, forcing experts and policymakers to find out options in this challenging situation. The challenges that the Indian educational system is facing during this pandemic outbreak are numerous. In an assessment Sahni (14 May 2020) elucidates, in India, 320 million students have been affected by COVID-19 school closures, and though the government quickly recommended shifting to "online teaching" this ignores India's immense digital divide-with embedded gender and class divides. What COVID-19 trajectory did, has exposed the loopholes in educational access on virtual platforms and significantly 3Ds Disparities, Differences and Dissimilarities.

There are both arguments in favour and argument against online pedagogy. Some scholars believe anywhere, anytime, anyplace, accessibility, unprecedented affordability, and studentcenteredness are the significant strengths of e-learning. Whereas, there is a class of scholars who believe lack of access and affordability, equity and flexibility, lack of essential online qualities and so on are the potential threats to the success of online teaching and learning. Nevertheless, across the globe, the spread of novel coronavirus COVID-19 has led to profound changes in social interaction and organization, and the education sector has not been insusceptible (Murphy, 2020).

The Indian government is and has been recognizing the importance of e-learning in this changing dynamic world by introducing various online platforms like Swayam. The closure of universities and colleges by the severe explosion of Corona Virus disease has led us to add to the existing arguments for online pedagogy. In the alternative argument, this chapter argues 'extraordinary times call for extraordinary measures' (Murphy, 2020)and created the phenomenon of emergency e-learning.

\section{Review of Literature}

Tremendous development in technology has contributed to reducing the "distance" that students experience in online learning and made it easy for learners to life-long learning (McBrien et al., 2009). Extending the meaning of e-learning, at one extreme is the e-learning as a philosophy of social learning, focused on student needs, formed at the junction of psychological and pedagogical dimensions and the networks (Demiray, 2010). "Most of the terms (online learning, open learning, web-based learning, computer-mediated learning, blended learning, m-learning, for ex.)have in common the ability to use a computer connected to a network, that offers the possibility to learn from anywhere, anytime, in any rhythm, with any means" (Cojocariu, et al., 2014). In the recent course of time web-based learning is used as another option to facing to face education. As a matter of fact, its use increases in a direct proportion with the increase of the number of students. This has made educators exert a lot of effort to help the learners to get interactive content that is full of multimedia as it has been proven that it has a significant effect on the process of learning (El-Seoud et al., 2014). The effectiveness of e-learning has increased in recent years. This is primarily due to the increased possibilities for IT and learning as well as increased political and organizational attention to 'what works' in learning (Noesgaard \& Ørngreen, 2015). Innovations in technology have led to the development of effective new methods 'emerging pedagogies' that have been identified in various researches on e-learning trends and have been taken to all stages of education. The instances of such experiences based on mobile learning, game-based learning, MOOCs, the flipped classroom, and learning analytics, all of which are becoming increasingly visible (Gros, 2016). In their research Basilaia et al. (2020) have identified certain criteria the online platforms for teaching and learning must meet during this Covid-19 pandemic:

a) Connecting with the lecture and at least 50 other students at the same time, via video interactive conference; 
b) In the case of online lectures, lecturers may need to use discussion to make the teaching process more organic and realistic;

c) For students, that don't have access to high-speed internet connections, the streams have to be recorded and uploaded;

d) The online lectures should be accessible not only by computers but mobile phones;

e) Should have the option to watch recorded lectures that they missed with the capability of rewind;

f) The ability for students to complete/hand in online homework, quizzes and tests.

The education sector has significantly responded to the demands of the Covid-19 crisis. Many online learning platforms are offering free access to their services, including platforms like BYJU'S, a Bangalore-based educational technology (Li \& Lalani, 2020).

In a study Anderson (2002) has expanded the theoretical base of online learning and proposed a model. "The model illustrates the two major human actors: learners and teachers, and their interactions with each other and with the content. Learners can, of course, interact directly and spontaneously with any content that they find, in multiple formats and especially on the Web; however, many choose to have their learning sequenced, directed, and credentialed through the assistance of a teacher in a formal education system. This interaction can take place within a community of inquiry, using a variety of net-based synchronous and asynchronous." The present research accepts the interactive nature of e-learning as proposed by Anderson in his study. Nevertheless, there are persistent challenges that hinder the progress and effective implementation of e-learning in times of pandemic, and even in normal circumstances.

\section{Methodology}

The nature of this study is descriptive. The challenges associated with online learning and possible solutions were identified based on previous literature. The research tool used for analyzing the data for this study is a content analysis and the research method is descriptive research. the qualitative aspects of this research study have been taken into consideration. This study is completely based on secondary data. A systematic review was done in detail for the collected literature.

In this study, in addition to a critical review of online learning during the COVID-19 crisis, the main focus is on the challenges and barriers that emerge out of pandemics over online educational attainment. The present paper seeks to:

a) Examine and explore the evolution of online learning.

b) Highlight the role of EdTech in times of pandemic.

c) Identify the challenges and barriers hindering effective implementation of E-learning.

d) Suggesting possible solutions for the effective implementation.

\section{Evolution of Online Learning}

Relatively the new technology has widened the scope of online learning, otherwise, the concept of online learning and education is nothing new to the world. Online Education ties together several historical threads-computers, distance learning, and telecommunications, just to name a few (Ferrer, 2019). It can be traced in the United States back to as early as the 18th century. Its evolution and progression over the last 300 years run parallel with innovations in communications technology, and distance learning continues to grow in popularity. Distance education was common beginning in the late 1800s, but its rapid growth began in the late 1990s with the advance of the online technical revolution (Kentnor,2015). In the 21st century world, the journey of distance learning continues beyond its horizons. By 2006 , "89\% of 4-year public colleges in the U.S. offer classes online, along with $60 \%$ of private institutions" and similarly by 2012 "Elite universities, such as Stanford, Harvard and MIT, rush to launch 
massive open online courses (MOOCs): free, not-for-credit courses offered on the Internet. The most popular MOOCs attract tens of thousands of students worldwide"(Debter, 2014).

In the early stages (prior to 2000) Indian e-learning market was not very responsive. In spite of the non-encouraging result, Indian players continued their attempts to make e-learning popular and acceptable in India. Tata Interactive Systems (TIS) was the first Indian organization that started the e-learning development initiative in India in a structured way (Roy, 2020). In a study Bansal (2017) advanced that KPMG India and Google has mentioned, developing countries like India are in a better position to ignore the erroneous models adopted earlier in advanced countries like the USA and leverage the latest advancements such as the hybrid model, the addition of new and offbeat subjects, gamification, peer-to-peer learning, and profile mapping. As per the analytics of research by Vivekananda and Ruvn (2017) the growth rate shows how each country adopts e-Learning and is a significant indicator since it can reveal revenue opportunities. The growth rate of self-paced e-learning by the different countries is:

Table 1. Growth Rate of Self-Paced E-Learning in Different Countries

\begin{tabular}{|c|c|c|}
\hline Rank & Country & Growth Rate in \% \\
\hline 1 & India & $55 \%$ \\
\hline 2 & China & $52 \%$ \\
\hline 3 & Malaysia & $41 \%$ \\
\hline 4 & Romania & $38 \%$ \\
\hline 5 & Poland & $28 \%$ \\
\hline 6 & Czech Republic & $27 \%$ \\
\hline 8 & Brazil & $26 \%$ \\
\hline 9 & Indonesia & $25 \%$ \\
\hline 10 & Colombia & $20 \%$ \\
\hline 11 & Ukraine & $20 \%$ \\
\hline
\end{tabular}

Source: Vivekananda, M. \&Ruvn, S. (2017), Emerging Trends of E-Learning in India

A report by KPMG and Google highlights that by 2021 the Indian online education industry is likely to witness a $6 \mathrm{X}$ growth. The adoption and assumption of e-learning technologies are supposed to expand from 1.6million users in 2016 to 9.6 million users in 2021 (Chaudhary, 2019).

\section{EdTech a Counter Response to Covid-19 Crises}

The EdTech journey in India began with the launch of Educomp. The first wave was led by Educomp, Everonn Education and Core Education among others, industries that focused on digitizing classrooms (Chakraborty, 2020). In India, education has been a segment steeped in a traditional brick-and-mortar delivery mechanism. The evolution of EdTech companies has entirely changed this model to the growing needs in the education sector. Byju's learning application became one of the most valued EdTech companies in the year 2019.

The EdTech Hub which is a joint initiative of Dfid, the World Bank and the Gates Foundation, is developing and sharing many reports and knowledge resources related to the use of Edtech during the COVID-19 pandemic. The need for education technology has clearly taken on a new level of urgency in light of COVID-19. Some companies have already seen this crisis as a window of opportunity. For example, in his recent blog for Forbes, "No, COVID-19 Is Not a Swell Chance to Market your Ed-Tech 'Solution'," Frederick Hess responds to the many pitches made by businesses to educators, promoting the adoption of new educational innovations in response to COVID-19's impact on schooling (Menashy, 2020). 
In India SWAYAM portal is an interesting educational platform that is initiated by the Ministry of Human Resource Development (MHRD), the Government of India to achieve three important objectives of educational policy, that is, access, equity, and quality. The foremost aim of SWAYAM is to provide online learning and unleash the digital divide (Dhawan, 2020). SWAYAM during the Covid-19 crisis has proven an alternative to the education community to continue learning via online mode. Owing to the COVID-19 pandemic, online teaching and learning had become an integral part of education, Delhi University has come up with 'OneDU'an online education programme to streamline the online education process (Tandon, 2020).

\section{Challenges in Pursuing Online Learning}

During the ongoing COVID-19 crisis online education has no doubt robust growth globally and in India particularly. There are several challenges associated with this journey. E-learning surfaces many challenges ranging from issues of a learner, educator's issues, and content issues. Comparing face-to-face learning with online learning brings forth significant deficiencies in the online mode such as lack of human connection, absence of opportunities for collaborative learning, teacher supervision and the most conspicuous being lack of opportunities for hands-on learning in complex subjects such as science and mathematics (Chari, 2020). An effort is directed to summarize the challenges emerging out of e-learning:

\section{Inadequate Digital Infrastructure}

Technology is a huge enabler, as it can be used to customize learning to learner's level, interest, academic and social needs. One of the ongoing challenges to e-learning is the insufficient accessibility of digital infrastructure. Various studies are revealing that low internet connectivity, whether at a university or home, is a preventing factor to e-learning (Al-Azawei et al., 2016). There are limitations in making entries to electronic databases to capture the requirements and support for student data warehousing, server technologies to host online learning systems, data rights, e-libraries, and general performance management. In the online learning process, the potential digital deficit includes poor network security, inadequate wireless technologies and low-speed internet bandwidths (Larbi-Apauet al., 2020).

\section{Inadequate Learning Engagement}

Looking at the conventional/traditional method of teaching and learning in classrooms the student-teacher and peer-to-peer engagement remain very high. Usually, in online learning, this engagement is less than a traditional method. Although students take online courses with the intention of successfully completing them, they tend to fail for a number of reasons. The success or failure of online instruction is perhaps related to student motivation (El-Seoud et al., 2014).

\section{Deficit Completion Rates}

The courses pursued through online learning are usually self-paced, the motivation for course completion is negligible. In a study, Jordan (2015) has analyzed that "completion rates vary significantly according to course length (longer courses having lower completion rates), start date (more recent courses having higher percentage completion) and assessment type (courses using auto-grading only having higher completion rates)." In a recent Forbes article Newton (2020) has examined and investigated that "Course completion rates are often low: around $20 \%$ " that is "among students who intend to complete" online courses.

\section{Low Level of Retention Among Online Learners}

Despite, the benefits of e-learning, online learning continue to exhibit serious retention issues. The fact that students are responsible to withdraw at any given stage of e-learning makes it even more crucial to search for ways and means to reconcile the underlining causes of this phenomenon (Bawa, 2016). Research cited by Sorensen and Donovan (2017) has categorized the factors of retention which increase dropouts into three groups: 
a) Student factors include academic background, relevant experience, skills, and psychological attributes.

b) Course/program factors include course design, instructional support, and interactions.

c) Environmental factors include work commitment and a supportive environment.

\section{Occurrence of Digital Divide}

In a study Mossberger, et. al. (2003) defined the digital divide as "the patterns of unequal access to information technology based on income, race, ethnicity, gender, age, and geography." Among the key issues and challenges addressing the digital divide is also important because technology can connect people to a wide range. The leaner who live in shelters and unstable housing makes offering accessible online education a challenge. Journell (2007) has concluded instead focusing on digital literacy and cultural barriers as perpetuating the divide, causing economic, democratic, and social ramifications for those affected. Nevertheless, there are swift advances in technology in the twenty-first century, the digital gap remains pervasive (Centeio, 2017).

\section{Language Problem}

In a country like India with multiple languages, non-English learners find it difficult to locate econtent in a vernacular language. Most of the online courses focus on English as the prime language. The e-learning companies must take this factor into consideration while trying to tap the market (Singh, 2019).

In a study, Al-Azawei et al. (2016) explored and identified the factors and challenges hindering the effective implementation of e-learning in developing countries. In this study, the authors have chronologically summarized various studies on major challenges that hinder the effective adoption of e-learning in developing nations.

\section{Figure 1. Challenges Hindering e-Learning in Developing Countries}

Challenges Hindering E-Learning Uptake in Developing Countries

\begin{tabular}{lcl}
\hline Study & Country & Challenges \\
\hline Sife et al. (2007) & Tanzania & $\begin{array}{l}\text { Systematic approach, awareness, and attitudes of } \\
\text { stakeholders, administrative support, technical support, } \\
\text { staff development, transforming Higher Education, lack } \\
\text { of funds, and ownership. }\end{array}$ \\
\hline Andersson (2008) & Sri Lanka & $\begin{array}{l}\text { Student support, flexibility, activities of teaching and } \\
\text { learning, internet access, student academic confidence, } \\
\text { localization of content to fit a particular culture, and } \\
\text { attitudes toward e-learning. }\end{array}$ \\
\hline Ssekakubo et al. (2011) & Africa & $\begin{array}{l}\text { Internet accessibility, knowledge gap of stakeholders, } \\
\text { ICT illiteracy, undefined strategies, inadequate selection } \\
\text { of LMSs, and inefficient user support. }\end{array}$ \\
\hline $\begin{array}{l}\text { Khan, Hasan, \& Clement } \\
\text { (2012) }\end{array}$ & Bangladesh & $\begin{array}{l}\text { ICT infrastructure, insufficient fund, unclear plan, } \\
\text { political factors, cultural factors, corruption, teachers' } \\
\text { attitudes, ICT skills, and lack of time. }\end{array}$ \\
\hline Elzawi \& Wade (2012) & Libya & $\begin{array}{l}\text { Internet access, low internet connectivity, lack of } \\
\text { encouragement, English proficiency, training programs, } \\
\text { cost of internet, technical skills, disinterest, and social } \\
\text { restrictions. }\end{array}$ \\
\hline Tarus et al. (2015) & Kenya & $\begin{array}{l}\text { ICTs and e-learning infrastructure, financial support, low } \\
\text { internet bandwidth, inadequate policies, technical skills, } \\
\text { teacher attitude, and time cost to prepare e-resources. }\end{array}$ \\
\hline
\end{tabular}

India has no exception to the challenges, the major hindrance to the acceptance of e-learning can be attributed to the Indian mindset that is more inclined to the traditional classroom or face-to-face learning (Imran, 2012). In the current (COVID-19) crisis online education has emerged as an alternative to ordinary face-to-face classes. Yet the barriers still exist in terms of 
financial constraints, unavailability of physical space, and discrimination against female learners (who are supposed to do domestic chores) (Singh, 2020).

\section{Implications}

To make online learning effective in times of disasters, focus on the use of technology more efficiently is needed. Therefore, it can be indicated that successful implementation of e-learning is not something that can be succeeded by installing an e-learning system. The learner's willingness and motivation make all this happen. What is important is the potential of responsive blended pedagogies to provide access to continued learning opportunities and enable student engagement in an extreme context. From the critical analysis of the literature the implications of e-learning during the COVID-19 crisis for wider audience's and governments bodies can be summarized as follows:

- Palvia et al. (2018) in their study has recommended that telecommunications infrastructure with a focus on high bandwidth connectivity needs to improve. This could happen in common sharing by advanced countries to developing nations.

- Another vital suggestive measure is that there is a need to train faculty on the use of online modalities and developing lesson plans with reduced cognitive load and increased interactivities (Mukhtar et al. 2020). One of the important needs of the hour is educators and students should be provided proper training to become efficient users of educational apps that are widely used globally like Zoom and Google classroom during the COVID-19 crisis.

- Effective and appropriate use of teaching strategies can be used to facilitate e-learning for efficient teaching and learning practices. The educator while imparting online education must keep in mind the five cardinal principles instruction, content, motivation, relationships, and mental health (Dhawan, 2020).

- The system of one size fits all does not apply in the circumstances where the pandemic has grappled the world. What is important is the right mix of localization, adjustment to cultural

diversity, and technology.

- The worst among challenges and issues during the COVID-19 crisis in online learning is the digital disparity of marginalized populations. In the time of crisis, like COVID-19, the policy-making bodies should create the opportunities for equitable online learning.

\section{Conclusion}

Information and technology have been considered central to the reform of the education system and have expanded unparalleled momentum during this pandemic. This research article makes a critical review of e-learning during the COVID-19 crisis. In a study, Ayebi-Arthur (2017) found that the college became more resilient to online learning after that disastrous event. In a similar way, Padernal (2020) answers the question of how disaster-proof education is a proactive measure that makes teaching and learning continue amidst calamities both natural and man-made? The answer to this question is education technology helps make this happen. Therefore, Disasters will continue to occur, they are sometimes natural in character and on the parallel side technologies will likely help us cope with them.

The challenges will always hinder the effective implementation of online learning in-depth. These challenges and factors may be internal or external such as lack of skills towards computer and e-learning technologies, unwillingness, disinterest, and demotivation etc. On the other side in a study Rapanta et al. (2020) have concluded that in the Covid-19 emergency situation, teachers have, almost overnight, been asked to become both designers and tutors, using tools that few have fluently mastered. Eventually, this Increases the stress level among the faculty, creating a condition of mental health issues in a wider perspective. Furthermore, the disasters and pandemics will halt the normal going of educational attainment, technology has always been there to assist to fill the gaps. 


\section{References}

[1]. Al-Azawei, A., Parslow, P. \& Lundqvist, K. (2016). Barriers and Opportunities of E-Learning Implementation in Iraq: A Case of Public Universities. International Review of Research in Open and Distributed Learning, 17(5), 126-146.

[2]. Anderson, T. (2002). Towards a Theory of Online Learning. Ottawa, Canada: Saint Paul University. Retrieved from https://ustpaul.ca/upload-

files /DistanceEducation/TOWARDS_A_THEORY_OF_ONLINE_LEARNING.pdf

[3]. Ayebi-Arthur, K. (2017). E-Learning, Resilience, and Change in Higher Education: Helping a University Cope After a Natural Disaster. E-Learning and Digital Media, 14(5), 259-274. DOI: https://doi.org/10.1177/2042753017751712

[4]. Bansal, S. (2017). How India's ed-tech sector can grow and the challenges it must overcome. VC Circle. Retrieved from https://www.vccircle.com/the-present-and-future-of-indias-onlineeducation-industry

[5]. Basilaia, G., Dgebuadze, M., Kantaria, M., \& Chokhonelidze, G. (2020). Replacing the classic learning form at universities as an immediate response to the COVID-19 virus infection in Georgia. International Journal for Research in Applied Science \& Engineering Technology, 8(III), 101-108.

[6]. Bawa, P. (2016). Retention in Online Courses: Exploring Issues and Solutions-A Literature Review. SAGE Open, 1-11. DOI: 10.1177/2158244015621777.

[7]. Centeio, E. E. (2017). The Have and Have Nots: An Ever-Present Digital Divide. Journal of Physical Education, Recreation \& Dance, 88(6), 11-12. DOI: https:/ /doi.org/10.1080/07303084.2017.1331643

[8]. Chakraborty, S. (2020). The huge investment opportunity in Edtech. Retrieved from https://www.forbesindia.com/article/edtech-special/the-huge-investment-opportunity-inedtech $/ 57733 / 1$

[9]. Chaplin, S. (2020). COVID -19: A Brief History and Treatments in Development. Prescriber, 31(5), 23-28. DOI: https://doi.org/10.1002/psb.18433

[10]. Chari, R. (2020). Challenges of quality in online learning. The Times of India. Retrieved from https:/ / timesofindia.indiatimes.com/blogs/edutrends-india/challenges-of-quality-in-onlinelearning/

[11]. Chaudhary, A. (2019). The growth magnitude of e-learning in India. Retrieved from https:/ / www.indiatoday.in/education-today/featurephilia/story/the-growth-magnitude-of-elearning-in-india-1628953-2019-12-17

[12]. Cojocariu, V. M., Lazar, I., Nedeff, V., \& Lazar, G. (2014). SWOT analysis of e-learning educational services from the perspective of their beneficiaries. Procedia-Social and Behavioral Sciences, 116, 1999-2003.

[13]. Debter, L. (2014). From Correspondence Courses to MOOCs: The Highlights of Distance Learning Over the Ages. Forbes Magazine. Retrieved from https:/ / www.forbes.com/sites/laurengensler/2014/02/12/from-correspondence-classes-tomoocs-the-highlights-of-distance-learning-over-the-ages / \# 19da94df7690

[14]. Demiray, U. (2010). e-LEARNING practices, Cases on challenges facing e-learning and national development: Institutional Studies and Practices, VOLUME: II, Anadolu University, EskisehirTurkey.

[15]. Dhawan, S. (2020). Online Learning: A Panacea in the Time of COVID-19 Crisis. Journal of Educational Technology,0(0), 1-7. DOI: 10.1177/0047239520934018

[16]. El-Seoud, M. S. A., Taj-Eddin, I. A. T. F., Seddiek, N., El-Khouly, M. M., \& Nosseir, A. (2014). ELearning and Students' Motivation: A Research Study on the Effect of E-Learning on Higher Education. International Journal of Emerging Technologies in Learning, 9(4), 20-26. DOI: http:/ /dx.doi.org/10.3991/ijet.v9i4.3465

[17]. Ferrer, D. (2019). History of Online Education. Retrieved from https://thebestschools.org/magazine/online-education-history/

[18]. Gros, B. (2016). The dialogue between emerging pedagogies and emerging technologies. In B. Gros, Kinshuk \& M. Maina (Eds.) The Future of Ubiquitous Learning, Lecture Notes in Educational Technology (pp. 1-23). Berlin-Heidelberg: Springer-Verlag.

[19]. Imran, S. M. (2012). Trends and Issues of E-Learning in Lis-Education in India: A Pragmatic Perspective. Brazilian Journal of Information Science: Research Trends, 6(2), 26-45. DOI: https:/ / doi.org/ 10.36311/1981-1640.2012.v6n2.03.p26 
[20]. Jordan, K. (2015). Massive Open Online Course Completion Rates Revisited: Assessment, Length and Attrition. International Review of Research in Open and Distributed Learning, 16(3), 341358.

[21]. Journell, W. (2007). The Inequities of the Digital Divide: Is E-Learning a Solution? E-Learning and Digital Media, 4(2), 138-149. DOI: https://doi.org/10.2304\%2Felea.2007.4.2.138

[22]. Kentnor, H. E. (2015). Distance Education and The Evolution of Online Learning in The United States; Curriculum and Teaching Dialogue. Information Age Publishing, Charlotte, 17(1/2), 2134.

[23]. Larbi-Apau, J., Sampong, K. \& Kwofie, B. (2020). Barriers to online learning adoption in higher education. University World News. Retrieved from https: / /www.universityworldnews.com/post.php?story=20200506200743715

[24]. Li, C. \&Lalani, F. (2020). The COVID-19 pandemic has changed education forever. This is how. Retrieved from https://www.weforum.org/agenda/2020/04/coronavirus-education-globalcovid19-online-digital-learning/

[25]. McBrien, J. L., Cheng, R., \& Jones, P. (2009). Virtual spaces: Employing a synchronous online classroom to facilitate student engagement in online learning. The International Review of Research in Open and Distributed Learning, 10(3), 1-17.

[26]. Menashy, F. (2020). Business engagement in education in emergencies: Lessons for the COVID19 response. Global Education Monitoring Report. Retrieved from https://gemreportunesco.wordpress.com/2020/04/08/business-engagement-in-education-inemergencies-lessons-for-the-covid-19-response/

[27]. Mossberger, K., Tolbert, C. \& Stansbury, M. (2003). Virtual Inequality: Beyond the digital divide. Washington: Georgetown University Press.

[28]. Mukhtar, K., Javed, K., Arooj, M., \& Sethi, A. (2020). Advantages, Limitations and Recommendations for Online Learning During Covid-19 Pandemic Era. Pakistan Journal of Medical Sciences, 36(COVID19-S4), S27-S31. DOI: https://doi.org/10.12669/pjms.36.COVID19-S4.2785

[29]. Murphy, M. P. A. (2020). COVID-19 and Emergency eLearning: Consequences of The Securitization of Higher Education for Post-Pandemic Pedagogy. Contemporary Security Policy, 41(3), 492-505.

[30]. Newton, D. (2020). The "Depressing" And "Disheartening” News About MOOCs. Forbes. Retrieved from https:/ /www.forbes.com/sites/dereknewton/2020/06/21/the-depressing-anddisheartening-news-about-moocs /\#26624cbd76ed

[31]. Noesgaard, S. S. \& Ørngreen, R. (2015). The Effectiveness of E-Learning: An Explorative and Integrative Review of the Definitions, Methodologies and Factors that Promote e-Learning Effectiveness. The Electronic Journal of eLearning, 13(4), 278-290.

[32]. Padernal, J. (2020). Why E-Learning is Key to Building Disaster-Proof Education. Neo Blog. Retrieved from https://blog.neolms.com/why-e-learning-is-key-to-building-disaster-proofeducation/

[33]. Rapanta, C., Botturi, L., Goodyear, P., Guàrdia, L., \& Koole, M. (2020). Online University Teaching During and After the Covid-19 Crisis: Refocusing Teacher Presence and Learning Activity. Postdigital Science and Education. DOI: https://doi.org/10.1007/s42438-020-00155-y

[34]. Roy, S. (2020). e-learning Scope and Trend in India. Retrieved from https://www.researchgate.net/publication/338913710_elearning_Scope_and_Trend_in_India?ch annel=doi\&linkId=5e32a40aa6fdccd96576de0b\&showFulltext=true

[35]. Sahni, U. (May 14, 2020). COVID-19 in India: Education disrupted and lessons learned. Retrieved from https://www.brookings.edu/blog/education-plus development/2020/05/14/covid-19-in-india-education-disrupted-and-lessons-learned/

[36]. Shukla, T. \& Nirban, V. S. (June 21, 2020). Covid has forced educational establishments to introduce e-learning tools, but the chasm between haves and have-nots is a concern. Retrieved from https://indianexpress.com/article/opinion/covid-has-forced-the-educationalestablishment-to-introduce-e-learning-tools-but-the-chasm-between-haves-and-have-nots-is-aconcern-6469841/

[37]. Singh, A. (2020). Online learning and education for all during and after the Covid-19 pandemic. Retrieved from https://www.financialexpress.com/education-2/online-learning-and-educationfor-all-during-and-after-covid-19-pandemic/2021940/

[38]. Singh, D. K. (2019). 10 Barriers to Overcome for Growth of Online Education in India. Retrieved from https://coursewareworld.com/online-learning-in-india-and-its-barriers / 
[39]. Sorensen, C. \& Donovan, J. (2017). An Examination of Factors That Impact the Retention of Online Students at a For-profit University. Online Learning, 21(3), 206-221. DOI: 10.24059/olj.v21i3.935.

[40]. Tandon, T. (2020). Delhi University News: Syllabus of 4 subjects approved, varsity launches One DU platform for online education. Retrieved from https:/ /www.timesnownews.com/education/article/delhi-university-news-syllabus-of-4subjects-approved-varsity-launches-one-du-platform-for-online-education / 633226

[41]. Vivekananda, M. \& Ruvn, S. (2017). Emerging Trends of E-Learning in India. International Journal of Advances in Electronics and Computer Science, 4(6), 1-6. 